\title{
Under the Maud-Moon
}

by Galway Kinnell

1

A fat-

cheeked girl-child comes awake

in her crib, chortling

and yodelling

to the day, the green

swaddlings tear open, a filament

or vestment tears,

and she who is born,

she who sings and cries,

she who begins the passage, her hair

sprouting out,

her gums budding for her first spring on earth, the mist still clinging

about her face, puts

her hand into

her father's mouth to clutch

his song.

2

It is all over, little one,

the flipping

and overleaping, the watery

somersaulting alone in the oneness

under the hill,

under the old lonely bellybutton

pushing forth again

in remembrance,

the drifting there furled in the dark, pressing

a knee or elbow down the slippery

wall, sculpting existence

with a foot, streams

of omphalos blood singing all about you.

\section{3}

Her head

enters the headhold

through which she starts rising:

being itself 
clamps down all over her, gives her into the shuddering grip

of departure, the huge, agonized clenches making the last perfect molds of her as she goes.

\section{4}

The eye

of darkness opens, the pupil

droozed with black hairs

stops, the chakra

on top of the brain

throbs a long moment in world light.

And she skids out on her face into light,

this peck

of stunned flesh clotted

with celestial cheesiness, glowing

with the astral violet

of the underlife. And as they cut

her tie to the darkness, she dies

a moment, turns

blue as a coal, the limbs shaking

as the memories rush out of them. And when

they hang her up by the feet

she sucks

air, she screams

her first song-and turns rose,

the slow,

beating, featherless arms

already clutching at the emptiness.

\section{5}

When it was cold

on our hillside, and you cried

in the crib rocking

through the darkness on wood

knifed down to the curve

of the smile, a sadness

stranger than ours, all of it

flowing from the other world,

I used to come to you

and sit by you

and sing to you. You did not know, 
and yet you will remember,

in the silent

zones of the brain, a spectre,

descendant of the ghostly forefathers, singing

to you in the night-time-not the songs

of light streaming

through the golden hair of the angels-

a blacker

rasping flowering on that tongue.

6

For when the Maud-moon

glimmered in those first nights, and the Archer

lay sucking

up the icy beestings

of the cosmos, in his crib

of stars,

I had crept down

to riverbanks, their long

rustle of being and perishing, down to marshes

where the earth oozes up

in cold streaks, touching the world

with the underglimmer

of the beginning,

and there learned my only song.

7

And in the days

when you find yourself orphaned,

emptied of wing-singing, of light, pieces

of cursed bread

on your tongue,

there shall come back to you

a voice, spectral,

calling you

sister! from everything which dies.

And then

you shall open

this book, even

if it is the book of nightmares. 